\title{
用于聚合物镍氢电池的新型 $\mathrm{PVA} / \mathrm{SiO}_{2}$ 碱性微孔聚合物电解质
}

\author{
陆霞吴仁香李波波朱云峰李李泉* \\ (南京工业大学材料科学与工程学院 南京新模范马路 5 号 210009)
}

\begin{abstract}
摘要 采用溶胶凝胶法, 结合相转移法和碱液活化法制备了 $\mathrm{PVA} / \mathrm{SiO}_{2}$ 碱性微孔聚合物电解质, 通过 $\mathrm{SEM}$ 、XRD、交 流阻抗法和循环伏安法表征了电解质的结构与电化学性能. 研究表明, $\mathrm{PVA} / 5 \omega \mathrm{SiO}_{2}$ ( $\omega$ 为质量分数)共混膜上的微孔大 小合适, 聚合物电解质的离子电导率最大可达 $1.62 \times 10^{-2} \mathrm{~S} \cdot \mathrm{cm}^{-1}$, 电化学稳定窗口 $2 \mathrm{~V}$ 以上; 将 $\mathrm{PVA} / \mathrm{SiO}_{2}$ 碱性微孔电 解质组装成聚合物镁基镍氢电池, 与传统镍氢电池相比, 循环稳定性大大增加.
\end{abstract}

关键词 聚乙烯醇; 碱性微孔聚合物电解质; 离子电导率; 循环稳定性; 聚合物 Ni-MH 电池

\section{Novel PVA/SiO ${ }_{2}$ Alkaline Micro-porous Polymer Electrolytes for Polymer $\mathrm{Ni}-\mathrm{MH}$ Batteries

\author{
$\mathrm{Lu}, \mathrm{Xia} \quad \mathrm{Wu}$, Renxiang Li, Bobo Zhu, Yunfeng Li, Liquan* \\ (College of Materials Science and Technology, Nanjing University of Technology, Nanjing 210009)
}

\begin{abstract}
New poly(vinyl alcohol)/silica (designated as $\mathrm{PVA} / \mathrm{SiO}_{2}$ ) alkaline micro-porous polymer electrolytes (AMPEs) were prepared by soaking PVA/ $/ \mathrm{SiO}_{2}$ micro-porous composite membranes, obtained by solution casting of $\mathrm{PVA} / \mathrm{PEG} / \mathrm{SiO}{ }_{2}$ membrane in acetone solution, into an electrolyte solution of $6 \mathrm{~mol} / \mathrm{L} \mathrm{KOH}$ aqueous solution. The morphology and structure of $\mathrm{PVA} / \mathrm{SiO}_{2}$ composite polymer membranes were characterized by scanning electron microscopy (SEM) and X-Ray diffraction (XRD). The SEM photographs showed that the nano- $\mathrm{SiO}_{2}$ filler content was a crucial issue for the well-dispersed and optimal-sized pores which could storage charge carrier durably. Meanwhile, the crystalline of PVA decreased effectively for a large number of crystal defects and free volume appeared in the interface of inorganic particles and polymer for the addition of nano- $\mathrm{SiO}_{2}$ filler. The electrochemical properties of the AMPEs were measured by the alternating current impedance (AC impedance) and the cyclic voltammetry (CV) techniques. The results indicated that the $\mathrm{PVA} / \mathrm{SiO}_{2} \mathrm{AMPEs}$ containing $5 \omega$ nano- $\mathrm{SiO}_{2}$ filler exhibited good performances at room temperature, such as $1.62 \times 10^{-2} \mathrm{~S} \cdot \mathrm{cm}^{-1}$ for ionic conductivity and $2.20 \mathrm{~V}$ for electrochemical stability window. What's more, we used the gravimetric method to obtain the electrolyte uptake of various $\mathrm{PVA} / \mathrm{SiO}_{2}$ composite micro-porous polymer membranes. From the data, we learned that the maximum electrolyte uptake could reach to $102.7 \%$ and it had very relevance to the size of pores in $\mathrm{PVA} / \mathrm{SiO}_{2}$ composite polymer membranes, and then influenced the ionic conductivity. Each polymer Ni-MH battery was assembled by three parts: the new AMPE, Mg-based hydrogen storage alloy and the commercial sintered $\mathrm{Ni}(\mathrm{OH})_{2} / \mathrm{NiOOH}$ electrode, in which each part did for electrolyte and diaphragm, negative electrode and positive electrode, respectively. The cycle experiments of the batteries exhibited a high first-cycle discharge capacity of $613 \mathrm{mAh} \bullet \mathrm{g}^{-1}$ and stable discharge capacities about $330 \mathrm{mAh} \bullet \mathrm{g}^{-1}$ for the following 5 cycles. The results encouraged that the novel AMPEs are prospective for the applications of polymer electrolyte in Ni-MH battery field.
\end{abstract}

Keywords PVA; alkaline micro-porous polymer electrolyte; ionic conductivity; cycling stability; polymer Ni-MH battery

\section{Introduction}

Mg-based hydrogen storage materials, act as the negative electrode materials in nickel-metal hydride battery (Ni-MH), have been attracting people's attention for their higher theoretical capacity $\left(999 \mathrm{mAh} \cdot \mathrm{g}^{-1}\right)$, lower specific weight and richer resource compared to $\mathrm{LaNi}_{5}$-based $\left(\mathrm{AB}_{5} \text {-type }\right)^{[1]}$ or $\mathrm{ZrV}_{2}$-based $\left(\mathrm{AB}_{2}\right.$-type) hydrogen storage materials. ${ }^{[2]}$ An innovative method integrating hydriding combustion synthesis (HCS) and mechanical milling (MM) has been proposed in our previous works ${ }^{[3]}$ to produce Mg-based hydrogen storage alloys with amorphous or nonacrystalline structures, which have a high electrochemical capacity $\left(996 \mathrm{mAh} \cdot \mathrm{g}^{-1}\right)$, timesaving and energy-saving advantages. ${ }^{[4]}$ As rechargeable cathode materials, Mg-based hydrogen storage alloy materials were easily corroded in alkaline solution, ${ }^{\left[{ }^{5}\right.}$ which leads to a decrease in discharge capacity and hinders their potential application in Ni-MH batteries. Making alkaline solid polymer electrolyte (ASPE) instead of the conventional alkaline aqueous electrolyte (i.e., $\mathrm{KOH}$ ) is considered as one of the

*E-mail: 1ilq@njut.edu.cn; Tel: 025-83587255

Received November 5, 2012; published February 1, 2013.

Project supported by National Natural Science Foundation of China (Nos. 51171079, 51071085), Specialized Research Fund for the Doctoral Program of High Education (No. 20093221110008) and Priority Academic Program Development of Jiangsu Higher Education Institutions (PAPD).

项目受国家自然科学基金(Nos. 51171079, 51071085), 教育部高等学校博士学科点专项科研基金(No. 20093221110008)和江苏高校优势学科建设工程 项目(PAPD)资助. 
most effective ways to overcome this critical problem. Limiting $\mathrm{OH}^{-}$in $3 \mathrm{D}$ network structure of polymer, it can greatly reduce the corrosion of $\mathrm{Mg}$-based alloy negative electrodes during the charge/discharge cycle. What's more, ASPEs can provide solutions to the problems of high internal pressure upon charging and alkaline leakage in $\mathrm{Ni} / \mathrm{MH}$ batteries. ${ }^{[6]}$

Compared with polyethylene oxide (PEO) and polyacrylic acid (PAA), polyvinyl alcohol (PVA) has been used as polymer matrix material in ASPEs for its moderate comprehensive performances in the aspects of ionic conductivity, tensile strength and chemical stability. However, none of simple PVA-based electrolytes could meet the requirements for practical application, so various approaches, such as blending, ${ }^{[7]}$ modifying with cross linking agent, ${ }^{[8]}$ adding plasticizer, ${ }^{[9]}$ as well as the addition of ceramic filler $^{[10]}$ have been explored. In recent years, the researches of porous polymer electrolytes have attracted great attention of scholars for their promising candidates in practical batteries. However, more studies focus on lithium-ion polymer batteries ${ }^{[11]}$ and fewer on alkaline batteries such as Ni-MH, Ni-Zn and Zn-air cells, etc. ${ }^{[12]}$

In our previous investigations, Chen et al. ${ }^{[13]}$ studied the preparation of PVA-based AMPE with a phase inversion process by using PEG for a pore-forming agent. Based on the previous works, we prepared a new PVA/ $/ \mathrm{SiO}_{2}$ AMPE and assembled the polymer Ni-MH batteries: the AMPE worked as diaphragms and electrolytes, the Mg-based hydrogen storage alloy materials for negative electrodes and the commercial $\mathrm{NiOOH}$ acted as positive electrodes. The discharge capacity of the polymer Ni-MH batteries and similar conventional cells with $6 \mathrm{~mol} / \mathrm{L} \mathrm{KOH}$ aqueous solution were tested for comparison.

\section{Results and discussion}

\subsection{Surface morphology}

SEM photographs of the top views of the micro-porous membrane (with different contents of nano-sized $\mathrm{SiO}_{2}$ ) and the corresponding bottom surface morphologies are shown in Figure 1(a) 1(b). The SEM photographs revealed that the holes in PVA matrix became smaller and more uniform with more nano-sized $\mathrm{SiO}_{2}$. But with $5 \omega$ more filler, the holes were heterogeneously-distributed and worsedispersed in one side, and crack even appeared. The micro-porous polymer membranes with well-dispersed and optimal size pores $(c a .8 \mu \mathrm{m})$ were obtained when adding 5 $\omega$ nano- $\mathrm{SiO}_{2}$ filler. The nano-sized $\mathrm{SiO}_{2}$, for its strong hydrophilic property, combined with water molecule in the form of hydrogen bond, so the local scope PEG content increased. After immersing in the acetone solution, PEG was dissolved for acetone's extraction ability and the appropriate-sized pores formed at the same time. However, too less nano- $\mathrm{SiO}_{2}$ filler in the PVA solution resulted in irregular large-sized pores for the heterogeneous dispersion. What's more, excessive nano- $\mathrm{SiO}_{2}$ filler tended to aggregate and caused dispersion problems in polymer host for its rigidity compared with $\mathrm{PVA},{ }^{[14]}$ so linear micro-crack appeared. The asymmetric pore structures in two sides of one membrane attributed to the faster decline rate of PEG than PVA, which was clearly discussed in lit-
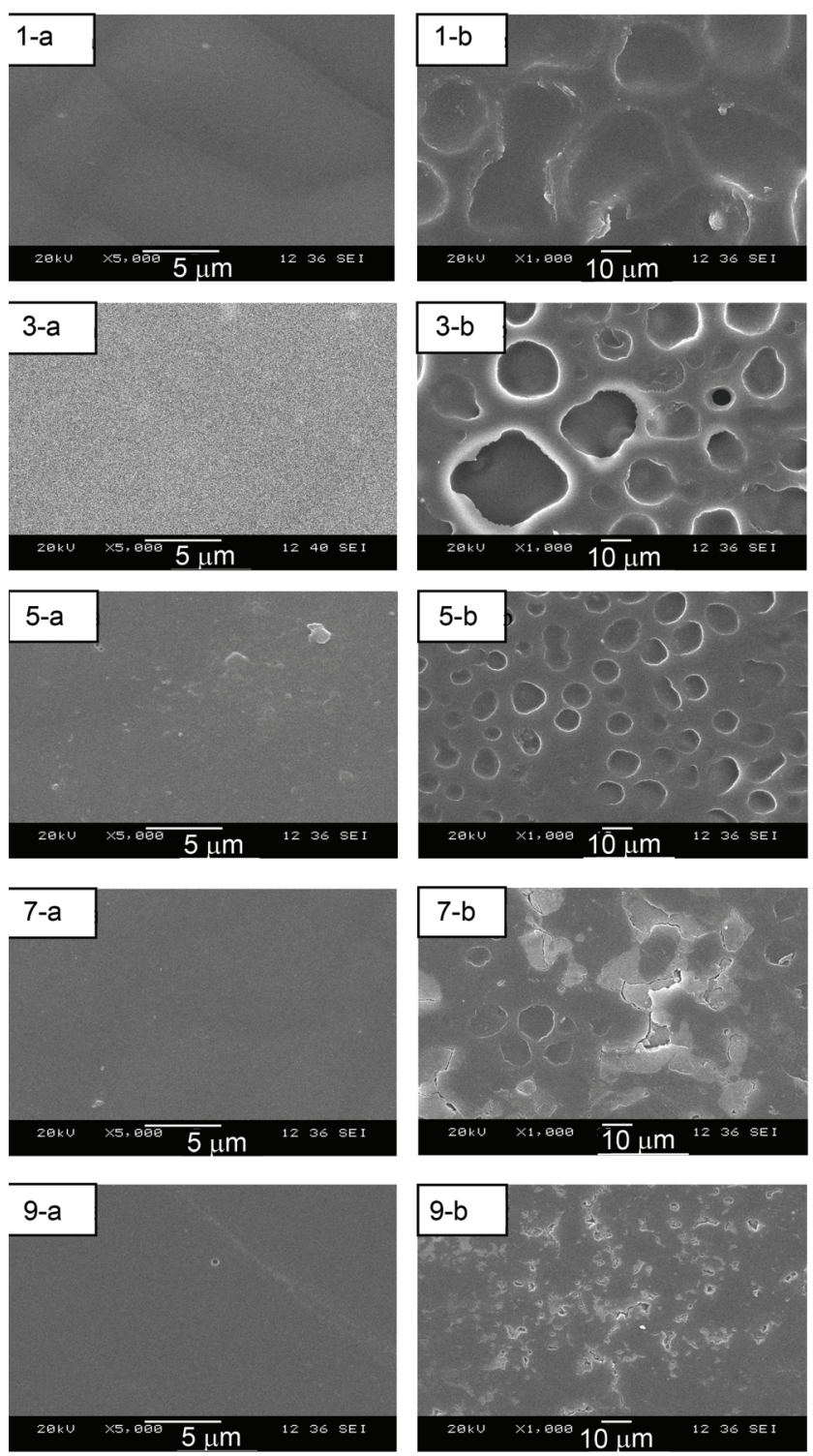

Figure 1 SEM photographs of PVA $X \omega \mathrm{SiO}_{2}(X=1,3,5,7,9)$ composite micro-porous polymer membranes with different contents of $\mathrm{SiO}_{2}$ : (a) the top surface (contacted with air); (b) the bottom surface (contacted with Petri dish during the process of membrane-forming).

erature. $^{[13]}$

\subsection{Crystal structure}

The X-ray diffraction measurement was performed to examine the crystallinity of the $\mathrm{PVA} / \mathrm{SiO}_{2}$ micro-porous composite membranes with different nano- $\mathrm{SiO}_{2}$ filler compositions. Figure 2 showed XRD curves of the pure PVA film and the PVA/PEG/0 $9 \omega \mathrm{SiO}_{2}$ composite membranes. The pure PVA polymer is well known to exhibit a semi-crystalline structure with a large peak at a $2 \theta$ angle of $19^{\circ} \sim 20^{\circ}$ and a small peak of $39^{\circ} \sim 40^{\circ}$. The PEG 2000 diffraction pattern exhibited the well-known intense diffraction peak located at $2 \theta=23.6^{\circ}$, which is characteristic of crystallized PEG. ${ }^{[15]}$ From curve (a) and curve (b) curve $(\mathrm{g})$, the large diffraction peak intensity of XRD for the PVA/PEG/0 $\sim 9 \omega \mathrm{SiO}_{2}$ composite membranes was obviously reduced after adding $\mathrm{PEG}$, which destroyed the 


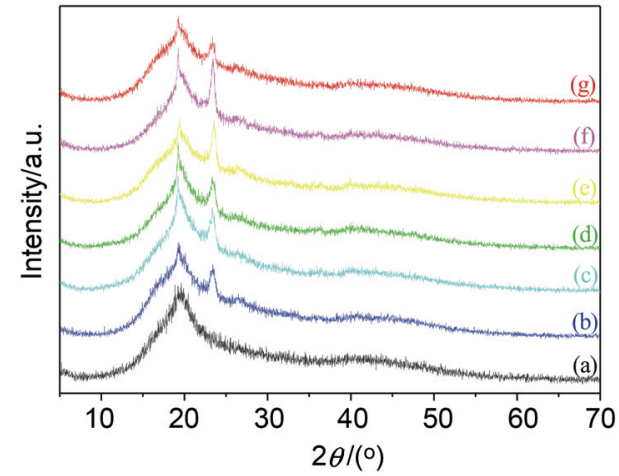

Figure 2 XRD patterns of PVA-based polymer membranes. (a) Pure PVA; (b) $\mathrm{PVA} / \mathrm{PEG}+0 \omega \mathrm{SiO}_{2}(\mathrm{PVA}: \mathrm{PEG}=7: 3$, below); (c) PVA/PEG $+1 \omega \mathrm{SiO}_{2}$; (d) PVA/PEG $+3 \omega \mathrm{SiO}_{2}$; (e) PVA/PEG $+5 \omega$ $\mathrm{SiO}_{2}$; (f) PVA/PEG $+7 \omega \mathrm{SiO}_{2}$; (g) PVA/PEG $+9 \omega \mathrm{SiO}_{2}$.

crystal structure of PVA and reduced the crystallinity degree of PVA. What's more, with increasing the content of nano- $\mathrm{SiO}_{2}$ filler, the relative intensity of the peak further decreased [curve (b) curve (g)]. This attributed to the fact that a large number of crystal defects and free volume appeared in the interface of inorganic particles and polymer for the addition of nano- $\mathrm{SiO}_{2}$ filler, so the crystalline of PVA decreased effectively and the proportion of amorphous region increased. It is well known that there's a significant motion of polymer chain in the amorphous phase area or the free-volume existing at the interface between polymer and ceramic filler, the improvement of ionic conductivity of PVA/ $/ \mathrm{SiO}_{2}$ composite polymer membranes must be due to the increased amorphous phase area or more free-volume in favor of local PVA chain segmental motion.

\subsection{Electrolyte uptake and ionic conductivity}

The AMPEs were prepared by immersing $\mathrm{PVA} / \mathrm{SiO}_{2}$ micro-porous composite membranes in $6 \mathrm{~mol} / \mathrm{L}$ alkaline solution. As we know, the nano-sized $\mathrm{SiO}_{2}$ inorganic particle, quite different from the ordinary $\mathrm{SiO}_{2}$, has the stable chemical properties: excellent tolerance to heat, acid and alkali. ${ }^{[16]}$ In other words, the nano-sized $\mathrm{SiO}_{2}$ can't react with any acid, alkali or organic solvent except the hydrofluoric acid and the hot caustic, so there's no worry about its reacting with cold $6 \mathrm{~mol} / \mathrm{L}$ alkaline solution, and quite a number of researchers focused nano- $\mathrm{SiO}_{2}$ filler on modifying PVA-based polymer electrolyte. ${ }^{[17]}$

Figure 3 showed the electrolyte uptake and the ionic conductivity of the PVA/1 $\sim 9 \omega \mathrm{SiO}_{2}$ micro-porous composite membranes with $6 \mathrm{~mol} / \mathrm{L} \mathrm{KOH}$ for $24 \mathrm{~h}$ at room temperature $\left(30{ }^{\circ} \mathrm{C}\right)$, and the detailed data was listed in Table 1.

From the result, it was found that both the electrolyte uptake and ionic conductivity were strongly depended on the inorganic filler content and the maximum electrolyte uptake of $102.7 \%$, the maximum ionic conductivity of $1.62 \times 10^{-2} \mathrm{~S} \cdot \mathrm{cm}^{-1}$ were achieved when the nano- $\mathrm{SiO}_{2}$ filler content was $5 \omega$. For AMPEs, the charge carrier $\left(\mathrm{OH}^{-}\right)$, acted as conductor, functioned for two parts: one is the $\mathrm{PVA} / \mathrm{SiO}_{2} / \mathrm{KOH}$ gel electrolyte and the other is the liquid electrolyte in the micro-porous, and which one play a dominant role is still a hot research topic. ${ }^{[18]}$ The excellent ionic conductivity could be one side attributed to the

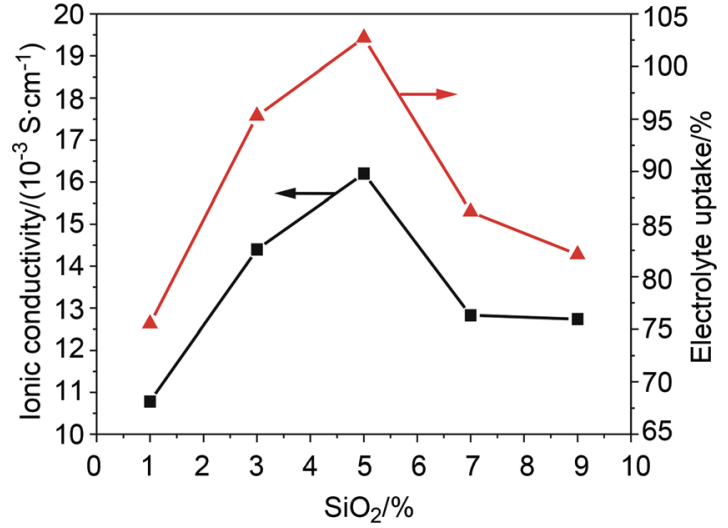

Figure 3 Electrolyte uptake and ionic conductivity of the PVA/1 $\sim 9 \omega$ $\mathrm{SiO}_{2}$ composite micro-porous polymer membranes at room temperature $\left(30{ }^{\circ} \mathrm{C}\right)$.

Table 1 Ionic conductivity and electrolyte uptake of AMPEs with various contents of $\mathrm{SiO}_{2}$

\begin{tabular}{cccc}
\hline S. No. & $\mathrm{SiO}_{2} / \omega$ & Electrolyte uptake $/ \%$ & $\sigma /\left(10^{-2} \mathrm{~S} \cdot \mathrm{cm}^{-1}\right)$ \\
\hline $\mathrm{S}-1$ & 1 & 75.5 & 1.08 \\
$\mathrm{~S}-3$ & 2 & 95.3 & 1.43 \\
$\mathrm{~S}-5$ & 3 & 102.7 & 1.62 \\
$\mathrm{~S}-7$ & 4 & 86.2 & 1.28 \\
$\mathrm{~S}-9$ & 5 & 82.1 & 1.27 \\
\hline
\end{tabular}

microstructure of the $\mathrm{PVA} / \mathrm{SiO}_{2}$ micro-porous composite membrane with an optimal size and well-dispersed pores with $5 \omega$ nano- $\mathrm{SiO}_{2}$ filler content, which could absorb and storage $\mathrm{KOH}$ solution electrolyte, increasing the number of the charge carrier in the PVA polymer matrix at the same time. On the other side, the addition of ceramic filler in polymer matrix reduced the crystallinity of the polymer for some defects and the free volume at the interface between the ceramic particles and the polymer, ${ }^{[19]}$ which increased the number of the ions transport tunnels, so the ionic conductivity increased.

With less nano-filler, there were large holes in PVA-SiO ${ }_{2}$ micro-porous composite membranes. With appropriate nano- $\mathrm{SiO}_{2}$ content, the mechanical property reached the best effect. But with excess filler, the aggregation appeared. The number of interface layers between the nano-filler and PVA polymer matrix decreased due to the partial aggregation, which resulted in the non-uniform pore distribution and linear crack, all of which led to the increase of brittleness in polymer membranes, and the mechanical strength decreased at the same time. ${ }^{[20]}$ Meanwhile, $\mathrm{KOH}$ electrolyte solution was easily evaporate and leaking from the porous membranes with large-sized holes with time, which resulted in a decrease of ionic conductivity, ${ }^{[7]}$ so the nano- $\mathrm{SiO}_{2}$ filler content was a crucial issue for the pore structure and distribution.

\subsection{Electrochemical stability measurement}

As a broad electrochemistry stability window is important for the practical application of the PVA/SiO 2 AMPEs, a cyclic voltammogram for the SS|AMPE|SS test cell was shown in Figure 4. The electrochemistry stability window was defined as a region without the flowing of the Faraday 
induced current and it was limited in its cathodic and anodic parts, where the reduction and oxidation of the polymer electrolytes and the $\mathrm{OH}^{-}$ions took place.

As shown in Figure 4, the stability window was about $2.2 \mathrm{~V}$ (from -1.1 to $1.1 \mathrm{~V}$ ) for PVA/5 $\omega \mathrm{SiO}_{2} \mathrm{AMPE}$, which could meet the requirement of its practical application in Ni-MH battery. Table 2 listed the electrochemical stability window values of $\mathrm{PVA} / \mathrm{SiO}_{2}$ AMPEs with various contents of nano- $\mathrm{SiO}_{2}$ filler. It was found that the adding nano- $\mathrm{SiO}_{2}$ filler had little impact on the electrochemistry stability. It should be noted, the interface area between the $\mathrm{PVA} / \mathrm{SiO}_{2}$ AMPE and the blocking electrolytes contained much more $\mathrm{KOH}$ electrolyte, so the electrochemistry window could be expanded. ${ }^{[17 \mathrm{~b}]}$

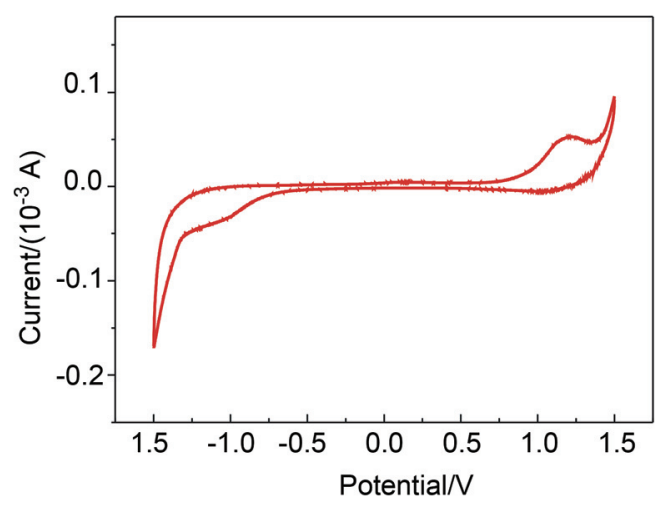

Figure $4 \mathrm{CV}$ curve of PVA $/ 5 \omega \mathrm{SiO}_{2} \mathrm{AMPE}$ containing $6 \mathrm{~mol} / \mathrm{L} \mathrm{KOH}$ electrolyte.

Table 2 Electrochemical stability window of PVA/X $\omega \mathrm{SiO}_{2}$ AMPEs.

\begin{tabular}{|c|c|c|c|c|c|}
\hline Nano- $\mathrm{SiO}_{2} / \omega$ & 1 & 3 & 5 & 7 & 9 \\
\hline Electrochemical stability window $/ \mathrm{V}$ & 2.1 & 2.1 & 2.2 & 2.2 & 2.2 \\
\hline
\end{tabular}

\subsection{Performances of polymer Ni-MH battery}

Figure 5 showed the discharge capacity as a function of the cycle number of the assembled polymer Ni-MH batteries and conventional cells measured at $\mathrm{C} / 5$ charge rate and $\mathrm{C} / 50$ discharge rate, respectively.

As shown in Figure 5, the first-cycle discharge capacity of the polymer Ni-MH batteries was up to $613 \mathrm{mAh} \cdot \mathrm{g}^{-1}$ which was comparable with the $\mathrm{KOH}$ electrolyte $\mathrm{Ni}-\mathrm{MH}$ batteries. In the second-cycle, the discharge capacity of the polymer Ni-MH batteries decreased to $331 \mathrm{mAh} \cdot \mathrm{g}^{-1}$ sharply, for which the highly active HCS + Mmed $\mathrm{Mg}_{2} \mathrm{NiH}_{4}$ alloys on the surface of the electrodes were corroded after the charge/discharge cycle. However, the next discharge capacities, nearly stable at about $331 \mathrm{mAh} \cdot \mathrm{g}^{-1}$, were higher than that of the traditional $\mathrm{KOH}$ electrolyte $\mathrm{Ni}-\mathrm{MH}$ batteries and other relevant documents obviously. ${ }^{[9,21]}$ These results revealed that the $\mathrm{Mg}_{2} \mathrm{NiH}_{4}$ alloys, inside of the electrode, were prevented more corrosion by using the PVA $/ \mathrm{SiO}_{2}$ AMPEs than the conventional $\mathrm{KOH}$ aqueous electrolyte and the corrosion resistance of the whole alloys improved.

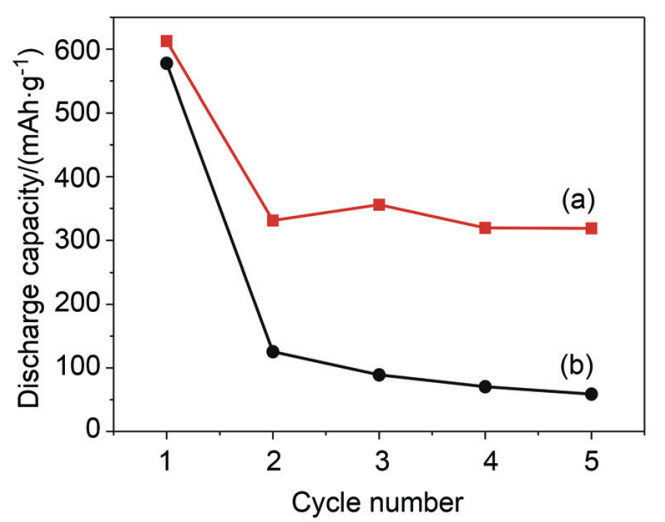

Figure 5 Discharge capacity of the assembled Ni-MH batteries measured at $\mathrm{C} / 5$ charge rate and $\mathrm{C} / 50$ discharge rate. (a) polymer $\mathrm{MH}-\mathrm{Ni}$ batteries; (b) conventional cells with $6 \mathrm{~mol} / \mathrm{L} \mathrm{KOH}$ aqueous electrolyte.

\section{Conclusions}

In this study, the novel $\mathrm{PVA} / \mathrm{SiO}_{2}$ micro-porous composite membranes were prepared by a phase inversion process, in which PEG acted as a pore-forming agent and dissolved in acetone solution later. SEM images indicated that the optimal-sized and well-dispersed pores were formed in PVA/5 $\omega \mathrm{SiO}_{2}$ membranes. XRD patterns showed a larger amorphous area existed in the PVA/PEG/0 $\sim 9 \omega \mathrm{SiO}_{2}$ micro-porous composite membranes. The PVA/ $/ \mathrm{SiO}_{2}$ AMPE with $5 \omega$ nano- $\mathrm{SiO}_{2}$ filler exhibited the maximum electrolyte uptake of $102.7 \%$, the highest ionic conductivity value of $1.62 \times 10^{-2} \mathrm{~S} \cdot \mathrm{cm}^{-1}$ and a electrochemical stability window of $2.2 \mathrm{~V}$ at room temperature. What's more, the first-cycle discharge capacity of the $\mathrm{Mg}_{2} \mathrm{NiH}_{4}+\mathrm{Ni}|\mathrm{AMPE}| \mathrm{Ni}(\mathrm{OH})_{2} / \mathrm{NiOOH}$ assembled batteries was up to $613 \mathrm{mAh}^{\bullet} \mathrm{g}^{-1}$, and the discharge capacities in the next cycles were nearly stable at $331 \mathrm{mAh}^{\bullet} \mathrm{g}^{-1}$, both were higher than that of the $\mathrm{KOH}$ electrolyte batteries and other researchers. These results showed an attractive potential of the PVA/SiO 2 AMPEs used in the application of the Ni-MH batteries.

\section{Experimental}

\subsection{Materials}

The main raw materials contained PVA powder $(\mathrm{DP}=$ 1700 and alcoholysis $=88 \%$, Fuzhou Quartet Chemical Industry Co., Ltd.), PEG $\left(M_{\mathrm{r}}=1900 \sim 2200\right.$, Shanghai Hongtu Chemical Reagent Factory), nano-SiO $2(10 \sim 50$ nm, Shanghai Haiyi Scientific \& Trading Co., Ltd), Mg powder $(\sim 177 \mu \mathrm{m}, 99.9 \%$ purity, Tianjin port of Fine Chemical Factory) and the Ni powder $(2 \sim 3 \mu \mathrm{m}, 99.7 \%$ purity, Shanghai metallurgical Metal Powder Co., Ltd.). Acetone and potassium hydroxide ( $\mathrm{KOH}, 85 \%$ purity) were purchased from Shanghai Lingfeng Chemical Reagent Co., Ltd. All the chemicals were used as received without further purification.

\subsection{Preparation of $\mathrm{PVA} / \mathrm{SiO}_{2}$ composite polymer membranes}

The PVA/ $\mathrm{SiO}_{2}$ micro-porous composite membranes were prepared by a phase inversion technique. An appro- 
priate quantity of PVA powder was dissolved in distilled water under stirring. The mixture was stirred continuously at $70{ }^{\circ} \mathrm{C}$ for $5 \mathrm{~h}$ until it became a homogenous viscous solution $(10 \omega)$. During the stirring, the nano- $\mathrm{SiO}_{2}$ powder with different weights $\left(\mathrm{SiO}_{2}: \mathrm{PVA}=1,3,5,7\right.$ and $\left.9 \omega\right)$ was added to the PVA solution to achieve a good dispersion. The temperature of the mixture was cooled to $30{ }^{\circ} \mathrm{C}$, after that a suitable amount of PEG (dissolved in acetone, PVA : $\mathrm{PEG}=7: 3$ ) was added dropwise into the mixture under a continuous stirring for $10 \mathrm{~h}$. The resulting solutions were poured onto a Petri dish and then the excess water was allowed to evaporate slowly at room temperature to form the PVA/PEG/ $\mathrm{SiO}_{2}$ composite membranes. Square pieces $(\mathrm{ca} .1 .5 \mathrm{~cm} \times 1.5 \mathrm{~cm})$, cut from the dried $\mathrm{PVA} / \mathrm{PEG} / \mathrm{SiO}_{2}$ composite membranes, were immersed in acetone at $30{ }^{\circ} \mathrm{C}$ for $24 \mathrm{~h}$ and it could dissolve the poreforming agent, namely $\mathrm{PEG}$, so $\mathrm{PVA} / \mathrm{SiO}_{2}$ micro-porous composite membranes with the thickness of $0.020 \sim 0.040$ $\mathrm{cm}$ were prepared.

\subsection{Electrolyte uptake, ionic conductivity and elec- trochemical stability window testing}

The pre-weighted $\left(W_{0}\right)$ and dried $\mathrm{PVA} / \mathrm{SiO}_{2}$ microporous composite membranes were immersed in $6 \mathrm{~mol} / \mathrm{L}$ $\mathrm{KOH}$ aqueous solution at $30{ }^{\circ} \mathrm{C}$ for $24 \mathrm{~h}$. The $\mathrm{PVA} / \mathrm{SiO}_{2}$ AMPEs were taken from the immersion bath and the excess solution was carefully removed by qualitative filter. The weight of the wet AMPEs $\left(W_{1}\right)$ was then determined. The electrolyte uptake of the PVA/SiO $\mathrm{S}_{2}$ AMPEs was calculated by the following equation:

$$
\text { Electrolyte Uptake } / \%=\left(W_{1}-W_{0}\right) / W_{0} \times 100
$$

Conductivity measurements on $\mathrm{PVA} / \mathrm{SiO}_{2}$ AMPEs were carried out by AC impedance method in a home-made cell. The PVA/ $/ \mathrm{SiO}_{2}$ micro-porous composite membranes were immersed in $6 \mathrm{~mol} / \mathrm{L} \mathrm{KOH}$ for $24 \mathrm{~h}$ before testing. The AMPEs were placed between two stainless steel (SS) electrodes, with a surface area of $0.785 \mathrm{~cm}^{2}$, in a spring-loaded PVDF holder. AC impedance measurements were performed using a CHI660C electrochemical workstation (CHENHUA, Shanghai). An AC frequency range from 100 $\mathrm{kHz}$ to $1 \mathrm{~Hz}$ at an excitation signal of $5 \mathrm{mV}$ was recorded. Nyquist plots were obtained from each electrolyte, and the resistances were extrapolated to their $\mathrm{x}$-axis intercepts. The procedure is the same as our previous work. ${ }^{[13]}$

Using the same SS|AMPE|SS cell and electrochemical workstation, the electrochemical stability window can be obtained by cyclic voltammogram for setting a cycle voltage region from $-1.50 \mathrm{~V}$ to $+1.50 \mathrm{~V}$ at a scan rate of 10 $\mathrm{mV} \bullet \mathrm{s}^{-1}$. Experimental temperature was maintained at 30 ${ }^{\circ} \mathrm{C}$. The conductivity and the electrochemical stability window measurements of AMPEs were examined at least three times.

\subsection{Morphology and structure investigation}

The surface morphology and microstructure of the $\mathrm{PVA} / \mathrm{SiO}_{2}$ micro-porous composite membranes were investigated by a JSM-6360LV SEM (JEOL, Japan) operating at $5 \mathrm{kV}$. Prior to the observations, the membrane samples were fractured in liquid nitrogen and sputtered with gold, then examined at $1000 \times$ and $5000 \times$ magnifications. The crystal structures of the $\mathrm{PVA} / \mathrm{SiO}_{2}$ micro-porous composite membranes were examined with an XRD (D/ Max-3A diffractometer, RIGAKU, Japan) using $\mathrm{Cu} \mathrm{K} \alpha$ radiation and operating at $35 \mathrm{kV}$ and $40 \mathrm{~mA}$. The membrane samples were scanned in the reflection mode with a $2 \theta$ angle between $5^{\circ}$ and $70^{\circ}$ with a scan rate of $5\left(^{\circ}\right)^{\bullet}$ $\min ^{-1}$.

\subsection{Polymer Ni-MH batteries and conventional cells measurements}

The $\mathrm{Mg}_{2} \mathrm{Ni}$-based hydride with high discharge capacity and activity was prepared by HCS + MM as described in our previous papers. ${ }^{[22]}$ The homogeneous mixture of $0.0412 \mathrm{~g}$ alloy powder and $0.1648 \mathrm{~g}$ carbonyl nickel powder was cold-pressed into a pellet of $10 \mathrm{~mm}$ diameter and about $0.5 \mathrm{~mm}$ thickness under the pressure of $10 \mathrm{MPa}$. Then the pellet was directly cold-pressed onto foamed nickel substrate $(c a .2 .0 \mathrm{~cm} \times 2.0 \mathrm{~cm})$ which worked as current collector. The electrochemical measurements were performed in half-cells consisting of negative electrodes ( $\mathrm{MH}$ electrode) and positive electrodes (commercial sintered $\mathrm{Ni}(\mathrm{OH})_{2} / \mathrm{NiOOH}$ electrode). The discharge capacities of the electrodes were evaluated by the amount of active substance $\mathrm{Mg}_{2} \mathrm{NiH}_{4}$ due to the excessive positive capacities.

The experimental polymer Ni-MH batteries were constructed by assembling PVA-SiO $\mathrm{S}_{2}$ AMPEs sandwiched between $\mathrm{Mg}_{2} \mathrm{NiH}_{4}$ hydrogen storage alloy electrode and sintered $\mathrm{Ni}(\mathrm{OH})_{2} / \mathrm{NiOOH}$ electrode as shown in Figure 6.

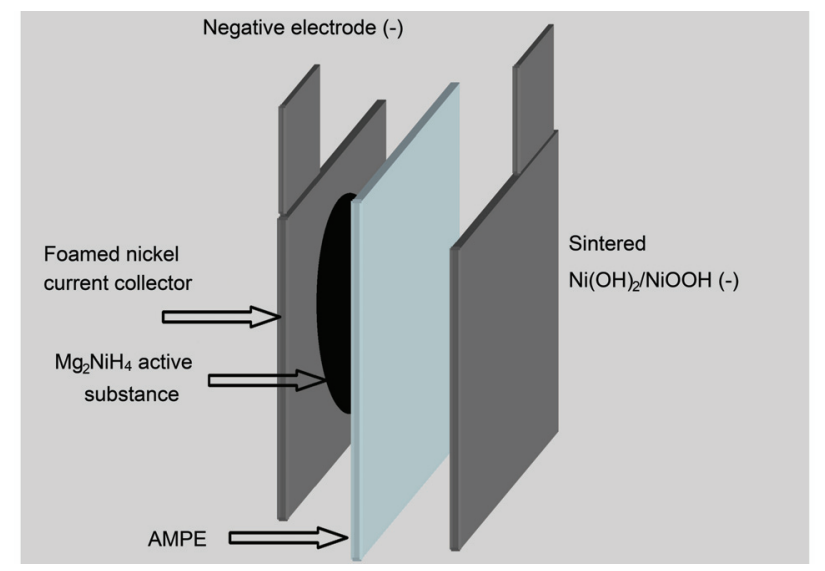

Figure 6 Schematic structure of the polymer Ni-MH batteries.

The assembled batteries were clamped with two slides in order to achieve a good electrode/electrolyte interface contact and then sealed with plastic film to prevent the evaporation of water in AMPEs. Conventional Ni-MH cells were also assembled with the same negative and positive electrodes but $6 \mathrm{~mol} / \mathrm{L} \mathrm{KOH}$ aqueous solution for comparison. All the tests mentioned above were examined at least three times.

The continuous current charge/discharge cyclings were determined by the LAND Battery Test Instrument (Six Dimensional Technology, Shenzhen). Each negative electrode was discharged at $60 \mathrm{~mA} \cdot \mathrm{g}^{-1}$ to the cut-off potential of $-0.6 \mathrm{~V}$ and then charged at $300 \mathrm{~mA} \cdot \mathrm{g}^{-1}$ for $3 \mathrm{~h}$ followed by $5 \mathrm{~min}$ rest. The discharge capacities of the batteries were evaluated by the active substances mass in the negative electrode. 


\section{References}

[1] Deng, C.; Shi, P.-F.; Zhang, S. Acta Chim. Sinica 2006, 64, 1031. (邓超，史鹏飞，张森，化学学报, 2006, 64, 1031.)

[2] (a) Zhao, X. Y.; Ma, L. Q. Int. J. Hydrogen Energy 2009, 34, 4788; (b) Liu, S.-Q.; Chen, D.-Y.; Huang, K.-L.; Zhong, X.-L. Acta Chim. Sinica 2009, 67, 513. (刘素琴, 陈东洋, 黄可龙, 仲晓铃, 化学学 报, 2009, 67, 513.)

[3] Zhu, Y. F.; Zhang, W. F.; Yang, C.; Li, L. Q. Int. J. Hydrogen Energy 2010, 35, 9653.

[4] Yang, C. M.S. Thesis, Nanjing University of Technology, Nanjing, 2011. (杨尘, 硕士论文, 南京工业大学, 南京, 2011.)

[5] Mohamad, A. A.; Mohamed, N. S.; Alias, Y.; Arof, A. K. J. Alloys Compd. 2002, 337, 208.

[6] Yuan, A. B.; Zhao, J. Electrochim. Acta 2006, 51, 2454.

[7] Qiao, J.-L.; Fu, J.; Lin, R.; Ma, J.-X.; Liu, J.-S. Polymer 2010, 51, 4850 .

[8] Yang, J.-M.; Chiang, C.-Y.; Wang, H.-Z.; Yang, C.-C. J. Membr. Sci. 2009, 341, 186.

[9] Mohamad, A. A.; Arof, A. K. Ionics 2008, 14, 415.

[10] (a) Yang, C.-C.; Chiu, S.-J.; Chien, W.-C.; Chiu, S.-S. J. Power Sources 2010, 195, 2212; (b) Sang, S. B.; Wu, Q. M.; Gan, Z. Electrochim. Acta 2008, 53, 5065.

[11] Boudin, F.; Andrieu, X.; Jehoulet, C.; Olsen, I. I. J. Power Sources 1999, 81, 804

[12] Yang, C. C.; Yang, J. M.; Wu, C. Y. J. Power Sources 2009, 191, 669.

[13] (a) Chen, Z.-Y.; Ju, Y.-L.; Zhang, W.-F.; Zhu, Y.-F.; Li, L.-Q. Mater. Rev. 2009, 23, 316. (陈忠元, 居亚兰, 张文峰, 朱云峰, 李李 泉，材料导报, 2009, 23, 316.); (b) Chen, Z.-Y.; Ju, Y.-L.; Zhang, W.-F.; Zhu, Y.-F.; Li, L.-Q. J. Funct. Mater. 2008, 39, 527. (陈忠
元, 居亚兰, 张文峰, 朱云峰, 李李泉, 功能材料, 2008, 39, 527.)

[14] Yang, C. C.; Chiu, S. S.; Kuo, S. C.; Liou, T. H. J. Power Sources 2011, 196, 4458.

[15] Rashkov, I.; Manolova, N.; Li, S. M.; Espartero, J. L.; Vert, M. Macromolecules 1996, 29, 50.

[16] (a) Li, Y.-J. M S. Thesis, Soochow University, Suzhou, 2011. (李延 洁，硕士论文，苏州大学，苏州，2011); (b) Yang，Y.-X.; Yang, B.-Y.; Duan, X.-J. Silicone Fluorine Info. 2004, 9, 27. (杨元秀, 杨 本意，段先健，有机硅氟资讯，2004，9，27.); (c) Yang, Y.-X.; Yang, B.-Y.; Duan, X.-J. Silicone Fluorine Info. 2005, 11, 40. (杨元 秀, 杨本意, 段先健, 有机硅氟资讯, 2005, 11, 40.); (d) Zhang, W.-H.; Fan, X.-D.; Tian, W.; Fan, W.-W.; Cheng, G.-W. Acta Chim. Sinica 2011，69，2047. (张卫红，范晓东，田威，范伟伟，程广文， 化学学报, 2011, 69, 2047.)

[17] (a) Lue, S. J.; Mahesh, K. P. O.; Wang, W. T.; Chen, J. Y.; Yang, C. C. J. Membr. Sci. 2011, 367, 256; (b) Yang, C. C.; Li, Y. J.; Liou, T. H. Desalination 2011, 276, 366; (c) Kim, D. S.; Park, H. B.; Rhim, J. W.; Lee, W. M. J. Membr. Sci. 2004, 240, 37.

[18] (a) Saunier, J.; Gorecki, W.; Alloin, F.; Sanchez, J. Y. J. Phys. Chem. B 2005, 109, 2487; (b) Kataoka, H.; Saito, Y.; Quaitarone, E.; Mustarelli, P. J. Phys. Chem. B 2000, 104, 11460.

[19] Yang, C. C. Mater. Sci. Eng. B 2006, 131, 256.

[20] (a) Michot, T; Nishimoto, A; Watanabe, M. Electrochim. Acta 2000, 45, 1347; (b) Chen, Z.-Y. M.S. Thesis, Nanjing University of Technology, Nanjing, 2009. (陈忠元, 硕士论文, 南京工业大学, 南京, 2009); (c) Suzuki, S.; Kimishima, K.; Takita, K. JP 2005082651-A, 2005 [Chem. Abstr. 2005, 20050331].

[21] Mohamad, A. A. Ionics 2005, 11, 294

[22] Zhu, Y. F.; Wang, Y. C.; Li, L. Q. Int. J. Hydrogen Energy 2008, 33, 2965. 